\title{
Informação, política e fé: o jornal Mensageiro da Paz no contexto de redemocratização do Brasil (1980-1990)
}

\author{
Information, politics and faith: the journal Mensageiro da Paz \\ in the context of redemocratization in Brazil (1980-1990)
}

André Dioney Fonseca*

\section{Resumo}

A Assembleia de Deus enfrentou uma série de pressões sociais relacionadas às mudanças que se processaram no Brasil na década de 1980: novos governos, nova Constituição, novos planos econômicos, novos movimentos políticos e manifestações culturais eram alguns dos elementos que direta ou indiretamente impunham novos desafios a essa Igreja na penúltima década do século XX. A Igreja, que até então mantivera uma postura de negação aos assuntos políticos, por julgar que esse tipo de tema pertencia estritamente ao plano terreno, recorreu a uma série de medidas para defender seus interesses e pontos de vista em uma nova conjuntura. O jornal Mensageiro da Paz teve, então, papel central como instrumento de propagação das suas mensagens. $\mathrm{O}$ artigo busca analisar as mensagens veiculadas nesse mensário por meio das quais a liderança assembleiana expressava seu descontentamento com os rumos políticos da nação brasileira e articulava a inserção de representantes da Igreja nas principais esferas políticas do país.

Palavras-chave: política; religião; Mensageiro da Paz.

\section{Abstract}

The Assembleia de Deus (Assembly of God) experienced a lot of social pressure because of the changes that occurred in Brazil in the decade of 1980: new government, new constitution, new economic plans, new political movements and cultural events were some of the elements that directly or indirectly imposed new challenges to its church in the penultimate decade of the twentieth century. The Church, that until the 80 's kept a posture of denial to the political issues, for thinking that kind of theme belonging strictly to the earthly plane, used a series of actions to defend its interests and points of view in a new situation. In that context, the journal Mensageiro da Paz had a central role as an instrument of propagation of the Church's messages. This paper seeks to examine the messages of this monthly publication through which the assemblies leadership expressed their dissatisfaction with the political direction of the Brazilian nation and articulated the inclusion of representatives of the Church in the main political spheres of the country.

Keywords: politics; religion; Mensageiro da Paz (journal).

\footnotetext{
* Doutorando em História Social, Universidade de São Paulo (FFLCH/USP). andredioney@usp.br
} 
Diante dos sucessivos desgastes dos governos militares ante a sociedade civil após o golpe que depôs o presidente João Goulart em 1964, o governo militar deu início, em meados da década de 1970, ao processo de abertura política no Brasil. O governo pautava-se num projeto estritamente vinculado a uma agenda eleitoral, ou seja, democratização entendida como possibilidade de eleição direta e não como um momento revolucionário guiado por uma agenda de reformas profundas no país. A transição deveria ser "lenta", "gradual" e "segura", por isso, conduzida pelo governo para não colocar em risco todos os esforços da "revolução" que havia "defendido" o país da "ameaça comunista" que representava a administração de Goulart.

No início da década de 1980 alguns passos importantes já haviam sido dados rumo à abertura democrática no país. O temido Ato Institucional número 5 (AI-5) havia sido revogado por Geisel, e no governo Figueiredo o Congresso conseguiu aprovar a anistia que permitiu a reintegração de políticos exilados e de ativistas perseguidos pelo regime militar à vida pública (Oliveira, 1994). Além disso, novos partidos políticos entraram na cena política graças à lei $\mathrm{n}^{\circ} 6.767$, de 1979, que pôs fim ao bipartidarismo. ${ }^{1}$ Após a reforma eleitoral de 1979, a Arena passou a se chamar Partido Democrático Social (PDS), e o $\mathrm{MDB}$ acresceu à sua antiga sigla a letra $\mathrm{P}$, passando a se chamar Partido do Movimento Democrático Brasileiro (PMDB). Surgiram ainda o Partido Popular (PP), o Partido Trabalhista Brasileiro (PTB), o Partido Democrático Trabalhista (PDT) e o Partido dos Trabalhadores (PT) (Vieira, 2000, p.205).

No pleito eleitoral de 1982, o governo militar conquistou a maioria no Colégio Eleitoral responsável por eleger o novo presidente. O PMDB, além de eleger governadores e senadores de nove estados, conseguiu duzentas cadeiras na Câmara dos Deputados. Com esse resultado, o PMDB, mesmo com o inquestionável poder ainda exercido pelos militares, colocava no cenário político novos atores que, investidos do poder que seus cargos lhes conferiam, poderiam lutar pelos ideais democráticos do partido (Kinzo, 2001, p.4-5).

Ocupados os cargos dos Executivos estaduais e do Legislativo federal, a agenda do momento passou a ser a sucessão presidencial. A proposta de eleição indireta sofria forte resistência, mas por iniciativa de um deputado do PMDB de Mato Grosso, Dante de Oliveira, foi apresentada em 1983 uma emenda a favor do voto direto. A proposta de Dante que, inicialmente, não teve grande ressonância, aos poucos foi ganhando adeptos até mobilizar milhões de pessoas em diversas passeatas e comícios por todo o país no movimento que ficou conhecido como "Diretas Já” (Rodrigues, 2003). 
O clamor popular, no entanto, foi vencido em 1984, quando a Emenda Dante de Oliveira foi derrotada no Congresso em razão de pressões e manobras do governo federal. Nessa situação, o caminho escolhido foi o da solução negociada, isto é, influir na sucessão presidencial, mesmo que ela ocorresse de forma indireta, sem enfrentamento com os militares, sobretudo, pelo risco de despertar a fúria da "linha-dura". Das negociações entre peemedebistas e os políticos que deixaram o partido do governo, surgiu a Aliança Democrática, cujo objetivo era levar Tancredo à Presidência da República (Lamounier; Meneguello, 1986). Com a vitória de Tancredo Neves e José Sarney em janeiro de 1985, o Brasil conseguiu restabelecer a democracia; no entanto, a Nova República nascia sob forte pressão política e econômica, sob o comando de José Sarney, um político que de mero elemento de negociação do PMDB com os dissidentes do governo militar, transformou-se, do dia para a noite, em presidente do Brasil com a morte de Tancredo Neves às vésperas de sua posse (Lopez, 1997).

Nesse contexto de tantas incertezas, diferentes organizações sociais buscaram demarcar espaço na "Nova República" que se anunciava e definir suas posições a respeito de diferentes questões. Foi o caso da Assembleia de Deus (AD), que teve de administrar uma dupla preocupação: participar dos debates políticos, já que o processo de redemocratização e a agenda de discussões inauguradas com a Nova República deixavam apreensiva a liderança da Igreja, e evitar que os pastores e fiéis se deixassem influenciar pela efervescente atmosfera política do país e "contaminassem" o espaço "sagrado" das igrejas com a política.

Do ponto de vista do sociólogo Francisco Cartaxo Rolim, a AD, tal como o pentecostalismo norte-americano que lhe deu origem, desde a fundação, manteve suas mensagens e suas práticas religiosas dissociadas de qualquer atividade social e política (Rolim, 1987, p.60-61). As demandas políticas pertenciam à esfera terrena, e o crente assembleiano deveria se preocupar com a vida no paraíso celestial onde, conforme a Bíblia, não haveria qualquer forma de dor e injustiça. Canalizar energia em busca de soluções para um mundo que biblicamente estava condenado ao fim, não fazia sentido para o fiel assembleiano; ele deveria orar pelas autoridades do país e se submeter às leis da nação, negando-se a participar de qualquer forma de ação contestatória ou revolucionária. A crença de que a segunda volta de Jesus poderia ocorrer a qualquer momento contribuía para desestimular a participação dos crentes em movimentos políticos e sociais, como bem apontou Francisco Cartaxo Rolim afirmando que o "mundo melhor" não resultaria da atividade humana, mas sim 
da intervenção do próprio Jesus Cristo (Rolim, 1987, p.47). Ainda segundo Rolim:

O pentecostalismo voltava-se para o cristianismo primitivo buscando reproduzir o que este apresentara de extraordinário na manifestação do Espírito Santo, isto é, orar e falar em línguas desconhecidas, fazer curas pelo poder divino. Isso significava introduzir no presente um modelo do passado. Só que este modelo é religioso e se pretendia alcançá-lo através de práticas religiosas. Quanto a mudar a sociedade, era coisa que se deixava por conta da segunda vinda de Cristo. (Rolim, 1987, p.54)

De acordo com Antonio Flávio Pierucci, nos anos 1980, em especial a partir das eleições pluripartidárias de 1982, os evangélicos passaram a almejar maior legitimidade ante a sociedade e deixaram para trás a velha frase tantas vezes defendida nos púlpitos e nos seus impressos: "crente não se mete em política" (Pierucci, 1996, p.163).

O processo de institucionalização do estado de direito e da democracia representativa e competitiva fez que as igrejas evangélicas deixassem a posição, que parecia inabalável, de alheamento político-social em busca de um novo modelo de atuação baseado na "publicidade". Para Pierucci, essa estratégia ocorreu em duas frentes principais: "1) procura [por] visibilidade para si diante da opinião pública, ou seja, notoriedade e popularidade, presença marcante na esfera pública midiática; e 2) parte para uma presença ativa na esfera pública propriamente dita, na esfera política" (Pierucci, 1996, p.167).

Até a primeira metade da década de 1970, havia três periódicos principais publicados pela CPAD: o Mensageiro da Paz (MP), jornal oficial da Igreja fundado em 1930; a revista $A$ Seara, destinada à publicação de "variedades", e a revista Lições Bíblicas, utilizada nas escolas dominicais. Em 1977, para atender especificamente os ministros da Igreja (pastores e evangelistas) foi fundada a revista Obreiro. A partir de 1979, na administração de Rangel Pires, foi lançada para o público jovem a revista Jovem Cristão e para o público feminino a revista Círculo de Oração. Além desses novos periódicos, no início dos anos 1980 a revista $A$ Seara, que desde 1956 circulara como um periódico multitemático, passou a publicar matérias específicas sobre o "lar e a família cristã".

Com esse novo quadro de distribuição de periódicos, o jornal MP, que até então circulava entre as igrejas por meio de assinaturas e de remessas de cotas às igrejas, buscou ampliar sua inserção no público que não pertencia à $\mathrm{AD}$. Com tal medida, buscava-se colocar o MP a serviço da evangelização e 
transformá-lo em instrumento de propagação e defesa dos princípios defendidos pela $\mathrm{AD}$ em um momento de importantes transformações sociais e políticas no Brasil.

A primeira mudança no MP nos anos 1980 ocorreu com a inclusão de notícias sobre o contexto político do país e, consequentemente, uma maior incidência de termos que antes raramente apareciam nas páginas do jornal, tais como "taxas de juros", "inflação", "crise econômica", "contexto político", "democracia”, "igreja e política”, "justiça social”, "liberdade religiosa no Brasil”, "movimentos sociais" e "engajamento político", entre outros. Os textos publicados no jornal também passaram a privilegiar referências mais genéricas como "nós, evangélicos" ou mesmo "nós, os crentes" ou ainda "nós, da Igreja de Cristo" ou simplesmente "a Igreja”, em detrimento de indicações diretas ao nome da Igreja como ocorria nas décadas anteriores, quando era comum encontrar a indicação "para nós da Igreja Assembleia de Deus" ou "as Assembleias de Deus no Brasil”.

Com essas reformulações, o MP passou a ser o porta-voz da AD em assuntos referentes à política, expressando os descontentamentos e as preocupações da liderança dessa Igreja diante do novo contexto social e político que se desenhava no início dos anos 1980. De acordo com as historiadoras Heloisa Cruz e Maria Peixoto é muito importante identificar a força histórica ativa das publicações em determinados momentos históricos, ou seja, como os impressos se colocam e atuam em relação à correlação de forças presentes em distintas conjunturas, quem são seus aliados ou amigos, que grupos ou forças sociais são identificados como inimigos, adversários ou forças de oposição (Cruz; Cunha, 2007, p.255).

No caso do MP, uma preocupação muito clara nos anos 1980 com os rumos políticos do Brasil e com as pressões exercidas por grupos "revolucionários". Assim, em julho de 1980 o editorial desse jornal expressou preocupação com os crescentes movimentos de contestação ao governo e o engajamento de grupos religiosos nas causas "revolucionárias":

A Palavra de Deus ensina dar a César o que é de César e a Deus o que é de Deus. Isso significa que o Estado existe dentro da vontade de Deus e ao Estado todos nós devemos obediência enquanto ele não se opuser à nossa fé. A Bíblia ensina que devemos estar sujeitos às autoridades superiores "porque não há autoridade que não proceda de Deus; e as autoridades que existem foram por ele instituídas", e a orarmos por ela ... O Senador Jarbas Passarinho afirmou, com razão, que "se o sermão passa a ser uma pregação oposicionista ao governo, aquele que profere 
exerce uma atividade nitidamente política limitada ao sentido temporal ... e por ocasião da greve dos metalúrgicos do $\mathrm{ABC}$, em São Paulo, a atuação política de alguns clérigos chegou mesmo a pregar às massas a mudança do regime vigente em nosso país. Saliente-se que esse tipo insidioso de pregação vem ocupando também alguns púlpitos protestantes em detrimento da sã doutrina da palavra de Deus. A história, todavia, tem muitas e sábias lições a dar aos teólogos contemporâneos, engajados em movimentos revolucionários. É impossível furtar-se às funestas consequências de uma transformação social que não seja a operada pelo genuíno Evangelho de Cristo, poder de Deus e sabedoria de Deus. Fora desta sólida e infalível base, as revoluções fracassam, porque os homens que as fazem não são regenerados, não são novas criaturas ... É fácil consertar o mundo quando primeiramente endireitamos o homem. A missão da Igreja é pregar a Cristo a toda criatura, a tempo e fora de tempo; é colocar as mãos no arado e não olhar para trás ... em uma palavra, transformar púlpitos em palanques políticos, ou substituir as Boas Novas de salvação por "slogans" revolucionários, é o mesmo que transformar bombeiros em incendiários. ${ }^{2}$

Com as discussões sobre a democracia e a possibilidade de participação político-partidária que lhe era inerente, a $\mathrm{AD}$ temia a oficialização de partidos com "ideais comunistas" que operavam, até então, na clandestinidade por causa da repressão do governo militar. José Marques de Melo destaca a importância do editorial para a demarcação da posição política de jornais e revistas, um espaço em que encontramos a opinião oficial de um periódico diante dos fatos de maior relevância num dado momento histórico (Marques de Melo, 1992, p.91).

O editorial do MP do mês de novembro de 1985, intitulado "Democracia e comunismo", em suas primeiras linhas era categórico: "A abertura trouxe os partidos comunistas de volta à legalidade. Doravante, estarão participando abertamente da vida política do país, em busca do voto de milhões de brasileiros". ${ }^{3} \mathrm{O}$ editorial alertava sobre o perigo por trás dos discursos inflamados em favor da democracia, da liberdade e em defesa dos trabalhadores que ecoavam por todo o país. Para o editorialista do jornal, eram esses mesmos discursos e ideais que levaram dezenas de países a se renderem ao manto do comunismo. E arrematava:

Como cristão não temos porque aceitar uma ideologia que, através do materialismo dialético, exclui Deus do controle do Universo, por considerá-lo uma utopia criada para enganar os povos sofridos do mundo. Tentar conciliar a doutrina 
cristã com tal conceituação, que massacra a vida religiosa, opondo à liberdade de suas manifestações, seria algo contrário ao bom senso. ${ }^{4}$

O MP também reprovava as ações de rebeldes que em nome da democracia promoviam terrorismo e desafiavam as autoridades constituídas. Radicais que lutavam pela implantação de um novo modelo de governo em que teriam espaço para propagar livremente suas "ideologias esquerdistas". Um artigo publicado em novembro de 1981 conclamava todos os evangélicos do Brasil para o dia nacional de jejum e oração pelo Brasil. Entre os problemas que motivavam as intercessões estavam: "terrorismo: no Brasil e no mundo, chamamos também de guerrilheiros, fazem misérias e dizimam grande número de vidas. Assassinos frios e cruéis ... sequestros, tanto de aviões, como de embaixadores, com o propósito de obrigar governos a pôr em liberdade assassinos violentos e perigosos". ${ }^{5}$ Conforme o artigo, era preciso mobilizar todas as igrejas para um dia especial de jejum e oração contra o "quadro terrível" vivido nos anos 1980, momento em que a "liberdade agonizava".

Sendo inadmissíveis as ideias revolucionárias, a junção da política com a religião e qualquer movimento de contestação à ordem instaurada, a $\mathrm{AD}$ tinha na Teologia da Libertação a síntese de tudo o que deveria ser combatido. Por isso, não media as palavras para criticar e chamar a atenção de seus fiéis para a malignidade incutida nesse movimento. Na década de 1980, foram dezenas de artigos publicados no MP contra os "teólogos da libertação" até mesmo com insinuações de que esse movimento representava o próprio "anticristo":

A Teologia da Libertação. Trata-se de uma teologia cristã só no nome, sem base bíblica, uma tentativa de associar ao cristianismo o pensamento marxista e dar ao cristão uma preocupação sociopolítica e ideológica com as coisas de Deus. Não temos dúvidas de que a Teologia da Libertação é uma ponta de lança do Anticristo ... há atualmente um movimento mundial em prol da ideologia marxista ou socialista, o qual está entrando na igreja com o nome de Teologia da Libertação. Uma observação, mesmo que superficial da Bíblia e dos Evangelhos, mostra que Deus, na sua revelação aos homens, sempre os advertiu a não amarem o mundo nem o que no mundo há. ${ }^{6}$

Para a AD, os problemas sociais, ainda que muito importantes, não deveriam ser uma preocupação da Igreja nem mesmo justificar a entrada da política no "espaço sagrado" das igrejas. O alvo do verdadeiro cristão não eram as forças terrenas, mas sim as hostes do mal e a incredulidade, esses, sim, fatores responsáveis por todas as injustiças sociais que afligiam o Brasil: 
Em referência aos pobres e injustiçados socialmente, nós lhes pregamos a salvação, e os ensinamos a terem confiança em Deus. Depois da pessoa ser salva a própria situação financeira melhora, porque Deus cuida dos seus. Mas lembramo-nos que o próprio Jesus foi pobre e injustiçado e no entanto perdoou aos seus algozes e afirmou, na hora da pronunciação de sua sentença, que seu reino não era deste mundo ... nossa luta não é contra a carne, nem contra as injustiças sociais, mas contra as potestades, contra o príncipe das trevas e contra as hostes espirituais ... o cristão que tem sabedoria não se deixa enredar nas teias romanas nem toma partido por ninguém a não ser por Jesus Cristo. ${ }^{7}$

A abertura democrática, além do apoio que recebia dos grupos de "esquerda" era um anseio da chamada "ala progressista" da Igreja Católica. Dessa forma, a $\mathrm{AD}$ temia pelo destino dos pentecostais com o fim do regime militar e implantação do novo governo. Esse sentimento de temor ficou claro em inúmeros artigos publicados no MP que tratavam das "ameaças à liberdade religiosa” que surgiam no bojo dos debates pela democracia.

Em fevereiro de 1984, uma chamada de capa do mensário oficial da AD, indagava: “Quem tem medo dos crentes?”. A chamada anunciava uma reportagem assinada pelo pastor Abraão de Almeida que denunciava uma conspiração da Conferência Nacional dos Bispos do Brasil (CNBB) para acabar com as "seitas" no Brasil. A matéria, que se baseava em reportagem publicada em um jornal secular, revelava a preocupação da CNBB com os ataques das seitas pentecostais à Igreja Católica e o alinhamento dessas seitas com o governo norte-americano que, segundo os documentos citados pela CNBB, chegava a apoiar financeiramente algumas denominações pentecostais.

Para o pastor Almeida, com esse tipo de postura a Igreja Católica, sobretudo os esquerdistas que nela se abrigavam, punha às claras quais eram seus objetivos ao defenderem a politização do povo e a revolução como forma de resolver os problemas da sociedade. Na verdade, de acordo com Abraão de Almeida, o que se queria era retomar a hegemonia católica que vinha perdendo espaço para as "seitas evangélicas", já que o clero católico nada mais fazia do que tentar doutrinar o povo politicamente nos seus núcleos de disseminação do marxismo denominados de CEBs (Comunidades Eclesiais de Base). ${ }^{8}$

No editorial de dezembro de 1984 do MP anunciou-se que o novo presidente do Brasil iria ser escolhido pelo Colégio Eleitoral, prenúncio da nova ordem política que se instalaria no Brasil. O texto destacou a importância dessa transição para a história política do país sem deixar de valorizar os serviços prestados pelo "ciclo revolucionário", representado pelos militares que se 
iniciou em abril de 1964, devido a um "quadro de instabilidade" no Brasil na década de $1960 .^{9}$

A matéria demonstrava pessimismo com os candidatos que disputavam o cargo mais importante do país, principalmente, pela luta que se travou entre os presidenciáveis: "parece até um paradoxo que dois pretendentes à suprema magistratura lancem mão dos mais variados recursos para que somente um deles se eleja ... afinal, estariam ambos movidos pelo desejo de servir ao povo brasileiro ou esta atitude revela apenas ambição pelo poder" indagou o editorialista. $^{10}$

Com o aumento da participação popular por meio de manifestações organizadas pelos movimentos sociais, $o$ artigo recomendava aos evangélicos que se mantivessem afastados da política, numa posição de "prudência" e de "não comprometimento" já que a Igreja, como instituição sagrada, pairava acima de "conceitos ideológicos" e "facções partidárias". O temor pelo que poderia vir na onda de democratização requeria cautela, e a $\mathrm{AD}$, segundo o editorial, tinha de preservar sua autonomia no novo regime para que, assim, pudesse combater os possíveis "pecados sociais" que poderiam surgir no novo cenário político. ${ }^{11}$

Mesmo pouco entusiasmada com a "Nova República" e com os presidenciáveis, a cúpula da $\mathrm{AD}$ apressou-se em se aproximar de Tancredo Neves, após sua vitória em 15 de janeiro de 1985 no colégio eleitoral. O encontrou mereceu destaque no editorial do MP de fevereiro de 1985, cujo título era: "Tancredo Neves e as Assembleias de Deus". ${ }^{12} \mathrm{O}$ editorial retratava uma audiência do recém-eleito presidente Tancredo Neves com um grupo de pastores da $\mathrm{AD}$, atendendo a solicitação do diretor da CPAD Custódio Rangel Pires. O editorial afirmava que no encontro os líderes assembleianos fizeram reivindicações sobre questões sociais, econômicas e também religiosas que interessavam a todos os evangélicos. Ao presidente foi apresentado um documento que buscava oficializar o "Dia nacional de jejum e oração" já que, segundo os pastores, os problemas que assolavam o Brasil eram muito mais de "ordem espiritual" do que de "ordem natural". O MP deu destaque à solicitação dos pastores para que o presidente retirasse os símbolos dos cultos afro-brasileiros que existiam na moeda brasileira, por serem esses cultos contrários aos princípios cristãos. $^{13}$

É interessante ressaltar que não esteve na pauta de reivindicações a reclamação sobre as perseguições da Igreja Católica aos pentecostais, omissão que talvez se explique pela filiação religiosa do novo presidente, que era católico. Apesar do destaque que se deu ao encontro dos pastores assembleianos com 
o presidente eleito e a satisfação da liderança assembleiana pela oportunidade estendida aos representantes da $\mathrm{AD}$ por Tancredo Neves, o próprio editorial negava aos leitores qualquer inclinação da $\mathrm{AD}$ em atuar na política e se referia ao encontro como uma abertura de diálogo entre o novo governo e os evangélicos:

Esse novo quadro que se antepõe diante da liderança de nossa igreja, não pretende assumir caráter de um alinhamento político-partidário. Não há porque comprometer a pureza do Evangelho com nuanças efêmeras decorrentes dos interesses se grupos que buscam o poder ... isto não quer dizer que somos alienados da realidade cotidiana. O compromisso da Igreja no contexto da sociedade é de tal monta que sua influência precisa ampliar os horizontes e alcançar, inclusive, os altos escalões do governo ... portanto, o diálogo iniciado entre os evangélicos e o próximo governo está longe de ser um envolvimento político o que não interessa a Igreja como instituição, ainda que individualmente, os crentes possam ter o direito de fazer suas opções. ${ }^{14}$

Após a morte de Tancredo em 21 de abril de 1985, a AD expôs seu descontentamento com a religião a que pertencia o falecido presidente. Trecho da reportagem que comunicava o falecimento de Tancredo no jornal MP indagava: "será que Tancredo Neves no exercício da presidência, como Católico praticante e devoto de São Francisco de Assis, teria condições de não se submeter a prováveis influências do clero romano?". ${ }^{15}$ A mesma reportagem exigia do novo presidente, José Sarney, o cumprimento das reivindicações que foram entregues em mãos ao presidente Tancredo Neves, além de alertar Sarney, que também era católico, sobre a constante tentativa da Igreja Católica em influenciar os rumos da Nova República.

Nos meses que se seguiram à morte de Tancredo, a $\mathrm{AD}$ reviu alguns posicionamentos relativos à política. A candidatura de membros e pastores, antes vista com desconfiança pela liderança da Igreja, passou a ser incentivada com a intenção de aumentar a representatividade evangélica no Executivo e no parlamento naquele contexto em que o Brasil dava seus primeiros passos rumo a uma nova ordem social. É o que se pode perceber nestes dois trechos de artigos publicados no MP de 1982 e 1985, respectivamente:

Quanto à política temos o que dizer: alguns defendem a participação da Igreja nessa área baseados na história dos judeus e não na origem da Igreja Primitiva, porque não teriam elementos para defenderem esse ponto de vista, senão para condená-lo. E o padrão de vida política dos judeus não pode ser tomado como 
base para a Igreja, porque esta não tem de lutar contra carne e o sangue, como aqueles. E se os judeus tinham de lutar, porque precisavam assumir uma posição política, e o fizeram para preservar a nação judaica, de onde mais tarde viria o salvador do mundo. E a Igreja, atuando na política, preserva o que? O Reino de Deus? Quando um pregador do Evangelho ocupa uma cadeira no parlamento, deixa de ter o mesmo vigor de evangelista, ainda que continue pregando eloquentemente. ${ }^{16}$

A Igreja de Cristo não foi colocada como cauda, e sim por cabeça. A Bíblia deixa subentendido que o cristão não pode eximir-se de suas responsabilidades com o mundo escondendo sua lâmpada debaixo do alqueire. Ora, isto significa dizer que precisamos do posicionamento de crentes fiéis em todos os setores da vida secular, incluindo-se aí o segmento político ... ou será que os descrentes são melhores do que os salvos para administrar a coisa pública? Pelo menos não é isso que a Bíblia deixa entender quando menciona o exemplo clássico de Daniel como governador da Babilônia, assessorado por Hananias, Mizael e Azarias ... podemos, também, mencionar José no Egito que soube administrar com austeridade aquela nação. ${ }^{17}$

Em novembro de 1985 foi aprovada uma emenda constitucional que autorizava a convocação da Assembleia Nacional Constituinte, um passo decisivo para a consolidação da democracia. A Constituinte, todavia, mais uma vez, punha em lados opostos os que reclamavam por amplas mudanças no quadro político-social, os que primavam por mudanças seguras e graduais e aqueles que queriam minar a Nova República. Conforme Francisco Carlos Teixeira da Silva:

Os partidos de esquerda, como o PDT, o PT, os partidos comunistas e uma parcela do PMDB esperavam, acima de tudo, remover o chamado "entulho autoritário": uma série de leis e atos que desde a implantação da ditadura limitava o exercício da cidadania ... ao mesmo tempo via-se a ocasião para a implementação de um sistema de benefícios de caráter universalista e distributivo que elevasse a situação social do povo brasileiro, particularmente através da ampliação do conceito de cidadania. Para a maioria do PMDB, por sua vez, e seus aliados do PFL, tratava-se de uma reforma jurídica, curta e enxuta, que permitisse que a vida do país se organizasse de acordo com regras representativas, corrigidas, entretanto, qualquer "excesso" democrático ... para os derrotados do PDS, tratava-se de uma trincheira de resistência contra a Nova República. (Silva, 1990, p.390) 
O lauto repertório de temas envolvido nas discussões sobre a nova Constituição atingia os interesses de diferentes segmentos da sociedade. Com a possibilidade de participação popular por meio de emendas populares, surgiram inúmeras campanhas em busca de assinaturas organizadas por universidades, sindicatos, órgãos do poder público, associações, organizações indígenas, entidades religiosas, grupos de estudantes, de idosos e de portadores de deficiência, entre outros. Um exemplo dessa mobilização foi o Movimento Nacional pela Participação Popular na Constituinte que aconteceu no Rio de Janeiro, onde se reuniram cerca de 7 mil pessoas na cidade de Duque de Caxias, com a presença de religiosos como o bispo Dom Mauro Morelli e de diversas organizações sociais, como a Ordem dos Advogados do Brasil (OAB), o Instituto Brasileiro de Análises Sociais e Econômicas (Ibase) e o Instituto de Estudos de Religião (Iser) (Michiles, 1989).

Após ampla discussão, o texto final da Constituição, que continha 245 artigos e 70 disposições transitórias, foi aprovado em 5 de outubro de 1988. A nova Constituição trazia grandes avanços. Assegurava eleições diretas e restringia a atuação das Forças Armadas, além de fazer a defesa de uma série de direitos civis e sociais que lhe rendeu o nome de "Constituição Cidadã" (Melo, 1990; Viana, 1983).

A partir dos primeiros passos do governo Sarney rumo à organização de uma Assembleia Constituinte, a $\mathrm{AD}$ iniciou uma verdadeira campanha no jornal MP em defesa da participação de evangélicos nos debates sobre a nova Constituição. A preocupação central da Igreja era com a atmosfera de "libertinagem" que a onda de democratização criava no país em prejuízo dos "bons costumes" que vinham cada vez mais sendo degradados na sociedade brasileira. Foi o que expressou o editorial do MP de abril de 1985:

$\mathrm{Na}$ atual fase de transição é preciso que se façam colocações sérias acerca do "modos vivendis" [sic] da nova república. Muitos confundem as mudanças propugnadas com a liberalização do comportamento, comprometendo assim a nossa já tão corrompida moralidade. Somos absolutamente intransigentes, quando indivíduos inescrupulosos, amantes da desgraça alheia e desejosos de lucro fácil, buscam aproveitar-se dos ventos democratizantes para transformar o nosso país em uma imensa terra de ninguém, onde a imoralidade seja o apanágio de todas as classes ... democracia não significa convivência com a degradação ... é preciso que o governo da nova república tenha credibilidade para coibir os abusos e estabelecer normas que protejam a sociedade contra os que desejam degradá-la. ${ }^{18}$ 
Convém observar que os textos publicados no MP em nenhum momento fizeram menção direta à participação de pastores ou membros da $\mathrm{AD}$ na Constituinte. Com o objetivo de se colocar como um interlocutor de todas as igrejas evangélicas, o MP mantinha em seus textos referências à importância da atuação dos "evangélicos" ou da "Igreja" na Constituinte, como em matéria publicada em julho de 1985 que alertava sobre a necessidade de a "Igreja" ter seus candidatos à Assembleia Constituinte para que estes, se eleitos, defendessem os princípios "evangélicos" naquele importante momento da história do país. ${ }^{19} \mathrm{O}$ texto ressalvava, no entanto, que os representantes evangélicos não deveriam ser eleitos para "pedir qualquer bem material ao governo", mas sim para defender a liberdade de manifestação religiosa, já que a Igreja Católica em vários momentos havia declarado sua preocupação com o crescimento dos evangélicos; ${ }^{20}$ posicionamento muito próximo ao que já havia sido defendido no editorial do MP em maio de 1985:

O compromisso da Igreja, nesse caso, não pressupõe um envolvimento político-partidário nem admite uma outra hipótese de segurança além daquela que nos é garantida por Deus. Representa, todavia, um esforço de manifestar sua benéfica influência nas mais altas esferas da vida pública. Existe, também, um outro aspecto do problema que não pode deixar de ser considerado. Enquanto estamos pensando em nossa participação, a Igreja Católica, ao lado de outros grupos religiosos, arregimenta suas forças e se prepara, através da CNBB para influir na próxima constituinte. E de que modo ela vai encarar a questão da liberdade religiosa? ${ }^{21}$

O editorial de julho de 1986 convocava todos os leitores, em nome da manutenção dos bons costumes e da preservação da liberdade religiosa, a depositarem seus votos em candidatos evangélicos. O texto ressaltava o papel desempenhado pelo MP na divulgação de assuntos relacionados ao quadro político do país e ressaltava a iniciativa pioneira do mensário em tratar desses assuntos "com a devida clareza". ${ }^{22}$ Outro aspecto interessante é a tentativa de conscientizar que a máxima "irmão vota em irmão" não significava que o evangélico deveria votar em qualquer "irmão". Ou seja, cada crente tinha de observar a indicação da Igreja e a vida pregressa dos candidatos que tamanha responsabilidade assumiriam ao representar os evangélicos na Constituinte. Ademais, defendia-se a união de todas as igrejas evangélicas do Brasil em prol da vitória do maior número de parlamentares evangélicos, deixando de lado velhas rixas que em um momento como esse poderiam enfraquecer a 
representatividade desse importante ramo religioso nas discussões da Assembleia Constituinte:

Se agirmos a partir desses pressupostos, estaremos contribuindo para a eleição de uma expressiva bancada evangélica e evitando que a fragmentação dos votos nos roube a singular oportunidade de termos pessoas preparadas e comprometidas com a fé cristã nos altos escalões na República. Do contrário, só nos restará a frustração de não sabermos fazer uso dos meios que Deus coloca em nossas mãos para tornar conhecido o seu nome ante as nossas maiores autoridades. Que o povo evangélico, sem cor denominacional, não se furte de cumprir com seu dever cívico e cristão. ${ }^{23}$

No mês de setembro de 1986, uma matéria especial que mereceu destaque de capa, apresentava aos leitores um conjunto de entrevistas com os principais candidatos evangélicos à Assembleia Constituinte e reforçava a importância dessa representação para a defesa dos interesses das igrejas evangélicas. Além dos candidatos, foram também entrevistados o reverendo Guilhermino Cunha, que pertencia à Igreja Presbiteriana do Rio de Janeiro e era representante dos evangélicos, sob indicação de Sarney, na Comissão de Estudos Constitucionais, o pastor Amaury Souza Jardim, da Igreja Congregacional de Bento Ribeiro e presidente do Comitê Evangélico Pró-Constituinte do Rio de Janeiro, e o secretário do Comitê, pastor Paulo Roberto de Oliveira Ramos, da Igreja Batista Monte Horebe, em Campo Grande, Rio de Janeiro.

Os candidatos ouvidos pela equipe do MP foram Amizael Gomes da Silva, da AD de Rondônia e presidente da Assembleia Legislativa desse estado; Benedita da Silva, da AD do Rio de Janeiro, vereadora e líder do seu partido na Câmara Municipal; Salatiel Carvalho, presbítero da AD de Abreu e Lima, em Pernambuco; Sotero Cunha, da AD de Madureira, no estado do Rio de Janeiro; João de Deus Antunes, evangelista da AD de Porto Alegre; Alfredo Reikdal, pastor da AD do Ipiranga, em São Paulo, e Carlos Apolinário da AD do Brás, também de São Paulo.

Antes de apresentar os pontos de vista dos candidatos, a matéria fazia uma inédita chamada à conscientização política dos leitores. Contrariando posições anteriormente defendidas no MP, o texto dava especial atenção aos problemas sociais do país, como a fome, a mortalidade infantil, o desemprego e, também, a premente necessidade de reforma agrária no país. A leitura de alguns trechos da matéria em nada faz lembrar as opiniões expressas em centenas de textos publicados no MP que consideravam pecado a contestação ao governo, 
atribuíam as mazelas sociais a causas meramente espirituais e defendiam a solução dos problemas pela via da oração e do jejum:

Como cidadão consciente e principalmente como cristão, é impossível não perceber as mazelas sociais à nossa vida. Os índices de mortalidade infantil por desnutrição crescem a cada dia e o desemprego assola com seus resultados desastrosos a milhares de famílias, enquanto a concentração de renda permanece nas mãos de uns poucos privilegiados. O presidente José Sarney tem encontrado numerosos obstáculos ao tentar pôr em prática a reforma agrária, ansiosamente esperada por aqueles que não têm nenhum direito a sua porção de terra, enquanto extensas regiões permanecem improdutivas. A violência urbana e rural cresce assustadoramente, sem que nenhuma medida funcione de forma objetiva. E onde está a participação do crente? O que tem sido feito no sentido de cobrar das autoridades uma atuação mais dinâmica diante de tantos desajustes? É preciso ir mais adiante, participando ativamente do processo de mudança social. E uma das condições para isso poderá estar na conscientização política, escolhendo acertadamente os candidatos que serão representantes do povo no Governo. ${ }^{24}$

Após o preâmbulo, a reportagem destacou a fala do reverendo Guilhermino Cunha em defesa de maior igualdade social no país: “A bandeira da justiça social é a bandeira do Evangelho de Cristo e a justiça deve presidir e permear todos os dispositivos atinentes à ordem econômica e social", ${ }^{25}$ afirmou o ministro presbiteriano.

A então vereadora Benedita da Silva, à época líder do Partido dos Trabalhadores (PT) na Câmara de Vereadores do Rio de Janeiro, defendeu sua candidatura sob a plataforma da justiça social: "Minha prática política é baseada na minha prática espiritual. Por isso, quero que todos tenham os mesmos direitos". ${ }^{26}$ A vereadora atacou os empresários evangélicos que exploravam os seus empregados ao dizer aos repórteres: "não compreendo como existem cristãos muito ricos e não dividem a riqueza nem com os empregados deixando até de pagar férias, $13^{\circ}$ salário e à noite estão nas igrejas, dirigindo cultos". ${ }^{27}$ A reportagem também ressaltou a luta da vereadora Benedita em favor da reforma agrária e deu destaque à resposta da candidata ao ser indagada sobre o tema: "essa discussão tem muita importância para mim, mesmo que tenha algum político evangélico e latifundiário, querendo defender suas terras. Minha participação será, sobretudo, a de uma serva do Senhor na Constituinte". ${ }^{8}$

Já o candidato Salatiel Carvalho demonstrou preocupação com os intentos da Igreja Católica na Constituinte: “A Igreja Católica quer controlar não só a 
Constituinte, mas toda a vida nacional ... A Constituição é o principal instrumento que a Igreja Romana vai usar" ${ }^{29}$ Salatiel preocupava-se também com os problemas sociais do Nordeste por considerar essa região do país fortemente marcada pelas desigualdades, e concluiu: "precisamos de uma Constituição que estabeleça os princípios de igualdade sem favorecer os já privilegiados, mas tornando-se um instrumento que garanta os direitos de todos".

O evangelista João de Deus Antunes firmava compromisso, caso eleito fosse, em lutar para frear os intentos das diversas organizações perniciosas que se mobilizavam para atuar na Constituinte: "O Partido Comunista está legalizado em 40 municípios gaúchos. Dom Elder Câmara faz uma jornada em todo o Brasil em nome da CNBB; os seguidores do reverendo Moon encontram-se mobilizados pela Constituinte. Os 'gays' já têm seus candidatos" ${ }^{30}$ Se os grupos dotados de ideias contrárias à "sã doutrina bíblica" estavam organizando-se, Salatiel não via sentido na omissão dos evangélicos com as causas políticas: “onde está a participação dos evangélicos? É tempo de agir, pois esta pode ser a última Constituição antes da volta de Cristo". ${ }^{31} \mathrm{O}$ deputado Carlos Apolinário, que pleiteava sua reeleição, garantia que se recebesse aprovação nas urnas daria continuidade a sua luta contra o aborto e contra o comunismo. Disse o deputado: "A presença dos evangélicos na Constituinte, demonstra, sem sombra de dúvidas, o seu patriotismo na discussão e votação da nossa Carta Magna".

Josué Sylvestre, autor do livro Irmão vota em irmão (1986), defendia a participação política dos evangélicos e manifestava-se contra a ideia há tanto tempo corrente nas igrejas de que política era pecado. Em defesa de seu posicionamento, lembrava aos que viam com maus olhos a participação de crentes nos pleitos eleitorais a vida pública de personagens bíblicas como Abraão, Moisés, José do Egito, Salomão e Josué: “Ao estabelecer um pacto com Abraão, Jeová adotou uma posição política. Ao fornecer a Moisés os fundamentos da Constituição de Israel (os 'Dez Mandamentos'), Jeová adotou outra posição política". ${ }^{32}$

O deputado estadual e então presidente da Assembleia Legislativa de Rondônia, Mizael Gomes da Silva, também se incomodava com a pouca representatividade evangélica nos poderes legislativos em tempos nos quais importantes decisões sobre o país estavam a cargo desses órgãos colegiados: "Quando se chega a Brasília e se encontra um ou dois crentes apenas para uma comunidade de milhões, fica-se surpreso, principalmente nesse momento histórico". ${ }^{33}$ No mesmo sentido, o pastor Alfredo Reikdal considerava que um dos fatores indispensáveis para melhor conscientização dos evangélicos com 
relação aos assuntos políticos seria o esclarecimento dos líderes que ainda traziam o "ranço de antigamente", estabelecendo barreiras entre seus liderados e o importante momento que estava sendo vivido pela nação.

O candidato Sotero Cunha ressaltou que o momento exigia cuidado redobrado para que o afã em eleger uma base evangélica no Legislativo não fosse uma porta de entrada para candidatos oportunistas. Sotero também lamentou a persistência de alguns evangélicos em esquivar-se da política, por temerem represálias por parte das lideranças. ${ }^{34}$

As entrevistas e a reportagem indicavam uma mudança na postura da $\mathrm{AD}$ em relação à atividade política. Palavras-chave dos discursos esquerdistas como justiça social, distribuição de renda, desemprego e reforma agrária, que em matérias anteriormente publicadas no MP foram duramente criticadas, alguns meses antes da eleição acabaram sendo admitidas no vocabulário assembleiano. Em total contradição aos textos veiculados no MP que atacavam a Teologia da Libertação e os movimentos de esquerda, a reportagem de setembro de 1986 chegou, até mesmo, a cobrar uma postura mais definida por parte dos fiéis ante as autoridades para que pudessem reivindicar melhorias no quadro social brasileiro. Mas o que parecia ser o sinal de uma nova relação da $\mathrm{AD}$ com a política revelou-se, na verdade, apenas uma jogada de marketing dos editores do MP para angariar votos aos seus candidatos, receosos que estavam com a eficácia dos discursos propagados pelos grupos de esquerda que poderiam calar fundo na população menos favorecida. ${ }^{35}$

As igrejas evangélicas saíram muito fortalecidas das eleições de novembro de 1986, posto que conseguiram eleger 33 deputados. Esse número colocava os evangélicos eleitos na situação de quarta maior bancada da Assembleia Constituinte, atrás somente do PMDB, do PFL e do PDS. Contudo, as urnas ainda trouxeram mais surpresas: dos 33 deputados eleitos 14 pertenciam à $\mathrm{AD}$ (Pierucci, 1996). Esse feito trouxe novo fôlego para a AD novamente dar as costas às "causas sociais" e influenciar seus parlamentares por meio do jornal MP para uma atuação estritamente conservadora e voltada aos interesses particulares da Igreja.

É o que se vê na matéria publicada em janeiro de 1987 no MP que anunciava o triunfo da $\mathrm{AD}$ nas urnas. O texto, antecipadamente, lembrava a importância do jornal MP para o sucesso alcançado nas urnas pelos candidatos: "A eleição desses evangélicos foi o resultado de um trabalho permanente de conscientização realizado por alguns órgãos da imprensa evangélica, entre eles o Mensageiro da Paz, que foi o primeiro a tratar do assunto". ${ }^{36}$ Além de saudar os irmãos recém-eleitos, a matéria também os advertia sobre seus deveres de 
parlamentares que representavam a Igreja. Foram listadas seis grandes diretrizes que deveriam nortear as atividades dos novos legisladores:

1. Uniformidade de ação, quando tratar-se de assuntos que interessem a comunidade evangélica, com destaque para a ética comportamental; 2. Identificação aberta com o Evangelho, sem subterfúgios, especialmente no relacionamento com a imprensa secular; 3. Sem cair nos extremismos, orientar-se pela Bíblia para encontrar respostas que solucionem as desigualdades sociais existentes no Brasil; 4 . Testemunho condizente com a vida cristã, pois todos estarão voltados para a ação dos evangélicos eleitos. Qualquer deslize será prejudicial ao nome da Igreja; 5. Não abandonar as bases, como fazem os políticos profissionais, mas prestar relatórios permanentes das atividades no Congresso Nacional; 6. Lembrar-se ainda de que acima das obrigações partidárias encontram-se os imutáveis e eternos princípios bíblicos, os quais devem nortear as atividades dos parlamentares cristãos. ${ }^{37}$

Diferentemente do teor do texto publicado em setembro de 1986, a matéria de janeiro de 1987 demonstrava pouca preocupação com as questões sociais e ao citá-las, como no item 3, orientava que os parlamentares buscassem as soluções para as desigualdades existentes no Brasil à luz da Bíblia, com cautela, evitando os extremismos. Toda aquela atenção dispensada às causas sociais na antevéspera da eleição pelo MP, foi deixada de lado. A reforma agrária, a distribuição de renda, o combate à fome e o desemprego nem sequer foram mencionados nos seis itens publicados que tinham por objetivo destacar os compromissos dos candidatos eleitos.

Ao se consultarem as edições do MP ulteriores a dezembro de 1986 fica evidente que a verdadeira intenção da $\mathrm{AD}$ no campo político não era lutar pela igualdade social. Dezenas de artigos publicados no mensário confirmam que o discurso de pré-eleição carregado de jargões denunciando as adversidades enfrentadas pela população brasileira não passava de mera retórica dos editores do MP num momento em que andavam à caça de votos para seus candidatos. Passadas as eleições, sem tergiversar, o MP voltou a sua tradicional postura política conservadora centralizada em três grandes frentes de atuação: 1) acompanhamento sistemático das atividades desenvolvidas pela Constituinte em temas que atentavam contra os dogmas da Igreja (aborto, defesa das minorias sexuais, liberdade de culto cristão, cerceamento dos cultos afro-brasileiros); 2) insistência na tese de que os problemas sociais no Brasil tinham caráter espiritual e não seriam resolvidos por meio de medidas políticas; 3) preocupação em evitar que os temas políticos ganhassem força nas igrejas além da 
reprovação às atividades de membros em movimentos sociais, em especial os de contestação às políticas governamentais.

Nem mesmo na nota comemorativa publicada em abril de 1987, na qual se anunciava a posse dos deputados evangélicos ocorrida em fevereiro, os editores do MP deixaram de reforçar seu posicionamento a respeito da atuação dos novos parlamentares. O texto era comemorativo, mas mesmo assim, não se furtava em realizar cobranças conforme se lê no título da notícia que demarcava uma das prioridades sobre as quais os deputados teriam de lutar na Assembleia Constituinte: "Constituintes evangélicos: somos contra o aborto". ${ }^{38}$

Em agosto de 1987, o editorial do MP fez um balanço da atuação dos parlamentares evangélicos na Constituinte. Novamente a preocupação central do MP, contrariando o que havia sido prometido meses antes da eleição, estava distante dos temas de interesse geral da sociedade, dos assuntos que poderiam influenciar direta ou indiretamente na melhoria de vida de milhares de brasileiros que conviviam então com o desemprego, com a fome, com uma tremenda desigualdade social, além das galopantes taxas de inflação, conforme se pode ler neste trecho:

ficou claro que o empenho de cada um foi efetivo seja na apresentação de sugestões ao texto constitucional, como na defesa de pontos com os quais não podiam transigir, entre eles obviamente o aborto e homossexualismo. É bom lembrar que os nossos irmãos enfrentaram às vezes ambiente hostil ... mas, pelo menos tiveram uma vitória parcial: o artigo que trata do aborto foi retirado, ficando para ser discutido a partir do momento em que o Congresso Nacional começar a reunir-se para adequar as leis ordinárias à nova Constituição. Todavia, o mesmo não ocorreu com a homossexualidade, assunto que ainda vai gerar grandes debates ... Não obstante à luta de nossos representantes, trata-se de um brecha para aceitação do homossexualismo como uma prática normal. ${ }^{39}$

A partir de 1988, o MP publicou uma série de textos que tratavam da situação do país e suas perspectivas futuras. Os prognósticos desalentadores eram marcados pela desqualificação da política como elemento capaz de resolver os problemas do Brasil. Ao colocar a política sob suspeita, desestimulava-se a militância por parte dos membros num momento em que muitos faziam "uso da abertura de forma errada". A política só interessava à Igreja se ela fosse utilizada, nas esferas competentes e legalmente reconhecidas, em defesa das sãs doutrinas da Igreja. Fome, desemprego, altas taxas de inflação, 
má distribuição de renda e da terra, e outros tantos desvios sociais, resultavam da má ordem espiritual do país que ainda conservava a cultura idólatra do catolicismo romano e as práticas satânicas dos cultos afro-brasileiros, além do homossexualismo e da prostituição que assolavam a nação. Essa era a ideia central do artigo publicado em julho de 1988, intitulado "Qual a solução para o Brasil?”, que lançava dúvidas sobre a eficácia dos planos políticos na resolução dos problemas sociais do Brasil e apontava os problemas oriundos do "excesso" de liberdade no novo regime político:

Na Assembleia Nacional Constituinte temos todas as camadas sociais representadas e nem sempre os pontos de vista são convergentes, o que é normal em um regime democrático. Mas isto acontece justamente em uma época de transição política em que há muita agitação, turbulência e insegurança. A grande dívida externa, o alto custo de vida, o grande número de desemprego, enfim, tudo concorre para que o negro e pesado clima paire sobre a nação causando terrível sensação de instabilidade ... Vive-se um momento decisivo, e muitas vezes manifestação acontece. Muitos do povo culpam a administração do país, dizem ser o Governo o responsável pela atual situação. E usando de meios condenáveis resolvem fazer justiça com suas próprias mãos. Fazendo uso da "abertura" de forma errada, incendeiam coletivos, agridem governantes, satirizam afirmações superiores e prosseguem gerando mais e mais insatisfações. Nós os salvos e remidos pelo sangue de Jesus, temos no tempo em que estamos vivendo, a responsabilidade de falar sobre a vontade soberana de Deus e orarmos pelo Brasil ... Ridicularizar governantes não tirará o país do caos em que se encontra. O povo tem o governo que merece, cremos. Se o povo for ímpio, terá ímpios governantes, porém se for fiel ao Senhor a benção de Deus será sobre todo o país. A nossa obrigação é respeitar as autoridades constituídas, pois foram elas colocadas onde estão com autorização de Deus. A solução não é simplesmente outro líder, mas a oração intercessora e objetiva ... é necessário que o nosso povo se humilhe verdadeiramente diante de Deus ... Abandonando a feitiçaria, a idolatria, a prostituição, o homossexualismo, enfim. ${ }^{40}$

Um mês antes do pronunciamento oficial de encerramento das atividades da Assembleia Nacional Constituinte, proferido pelo deputado Ulisses Guimarães em outubro de 1988, o MP publicou um artigo que relativizava a importância da Constituição para a vida do verdadeiro cristão. O conteúdo do texto em nada lembrava o entusiasmo dos líderes assembleianos nas eleições de novembro de 1986, momento em que a Igreja, sentindo-se ameaçada, 
buscou conscientizar os evangélicos sobre a importância de uma Constituição para o futuro do país e com muito afinco alavancou a candidatura de representantes para compor a Assembleia responsável pela formulação do texto constitucional:

O cristão autêntico não depende para viver a vida pessoal ou social com nobreza e dignidade de "constituições periódicas" que vão se adaptando às circunstâncias ditas novas. Vivendo de acordo com a Bíblia, a Palavra de Deus - o cristão pende sempre para os valores mais altos da vida e busca o bem para si e para seus semelhantes ... temos Nova Constituição em nossa Pátria. Será definitiva? Será acatada e obedecida? Pelas lições do passado nos tornamos um tanto duvidosos a respeito. ${ }^{41}$

Pode-se afirmar, a partir do exposto até aqui, que a $\mathrm{AD}$ aproximou-se do campo político porque queria assegurar seu lugar na nova conjuntura social que se anunciava na década de 1980. Para isso, esforçou-se para eleger seus candidatos com o intuito de aumentar sua representatividade na Constituinte, fórum central de definição dos rumos do país naquele momento. Em busca desse intento, chegou, até mesmo, a recorrer a palavras de ordem utilizadas pela esquerda a que sempre recriminara; passado, todavia, o perigo da homogeneização dos debates pelos blocos esquerdistas e católicos na Constituinte e com o expressivo resultado alcançado nas urnas, a AD buscou encontrar uma posição política estratégica na nova ordem social. Qual seja, utilizar sua força política em defesa dos interesses específicos da Igreja, evitando embates com o governo e a entrada de assuntos políticos nos templos.

O jornal MP teve aí uma função muito importante nas estratégias da AD. Ao mesmo tempo em que cumpria sua função de veículo informativo, com a publicação de notícias inerentes à Igreja e aos principais acontecimentos do cenário nacional, o jornal também servia como porta-voz da $\mathrm{AD}$ em assuntos relacionados à política, o que fez com que o padrão tradicional do jornal fosse alterado ao se diminuir o espaço destinado a matérias estritamente teológicas. Disso pode-se afirmar que a política editorial do MP pautou-se nos anos 1980 na tríade informação, política e fé, isto é, um jornal cuja missão seguia esta ordem de prioridade: 1) manter os seus leitores informados sobre as transformações que estavam ocorrendo no país; 2 ) alertá-los de forma clara e objetiva sobre os desafios da Igreja no conturbado contexto político dos anos 1980; e 3) subsidiar os ensinamentos teológico-doutrinários que eram adquiridos nos templos. 


\section{REFERÊNCIAS}

CRUZ, Heloisa Faria; CUNHA, Peixoto Maria. Na oficina do historiador. Conversa sobre história e imprensa. Projeto história, São Paulo, n.35, 2007.

FRESTON, Paul Charles. Protestantes e política no Brasil: da Constituinte ao Impeachment. Tese (Doutorado em Sociologia) - IFCH, Unicamp. Campinas, SP, 1993.

KINZO, Maria D’alva Gil. A democratização brasileira: um balanço do processo político desde a transição. São Paulo em Perspectiva, São Paulo, v.15, n.4, p.3-12, 2001.

LAMOUNIER, Bolívar; MENEGUELLO, Rachel. Partidos políticos e consolidação democrática: o caso brasileiro. São Paulo: Brasiliense, 1986.

LOPEZ, Luiz Roberto. Uma História do Brasil: República. São Paulo: Contexto, 1997.

MACIEL, David. Argamassa da Ordem: da ditadura militar à Nova República (19741985). São Paulo: Xamã, 2004.

MARQUES DE MELO, José (Org.) Gêneros jornalísticos na Folha de S. Paulo. São Paulo: FTD, 1992.

MELO, Marcus André. A formação de políticas públicas e a transição democrática. O caso da política social. Dados, Rio de Janeiro, v.33, n.3, p.443-470, 1990.

MICHILES, Carlos. Cidadão constituinte: a saga das emendas populares. Rio de Janeiro: Paz e Terra, 1989.

OLIVEIRA, Eliézer Rizzo de. De Geisel a Collor: Forças Armadas, transição e democracia. Campinas, SP: Papirus, 1994.

PIERUCCI, Antônio Flávio. Representantes de Deus em Brasília: a bancada evangélica na constituinte. In: PIERUCCI, Antônio Flávio; PRANDI, Reginaldo (Org.) A realidade social das religiões no Brasil: religião, sociedade e política. 1.ed. São Paulo: Hucitec, 1996.

RODRIGUES, Alberto Tosi. Diretas Já: o grito preso na garganta. São Paulo: Ed. Fundação Perseu Abramo, 2003.

ROLIM, Francisco Cartaxo. O Que é Pentecostalismo? São Paulo: Brasiliense, 1987.

SILVA, Francisco Carlos Teixeira da. Brasil, em direção ao século XXI. In: LINHARES, Maria Yeda (Org.) História Geral do Brasil. 9.ed. Rio de Janeiro: Campus, 1990.

SYLVESTRE, Josué. Irmão Vota em Irmão. Brasília: Pergaminho, 1986.

VIANA, Luiz Werneck. O Problema da Cidadania na hora da Transição Democrática. Dados, v.26, p.243-264, 1983.

VIEIRA, Evaldo. Brasil: do golpe militar à redemocratização. In: MOTA, Carlos Guilherme (Org.) Viagem incompleta: a experiência brasileira (1500-2000). A grande transação. 2.ed. São Paulo: Ed. Senac, 2000. 


\section{NOTAS}

${ }^{1}$ A medida que propunha o fim do bipartidarismo tinha por objetivo enfraquecer a oposição, pois num cenário aberto à fundação de novos partidos os oposicionistas que se concentravam em um único partido se fragmentariam. A fragmentação aumentaria o poder de barganha e de supressão aos políticos que eram contrários ao governo, como confirma David Maciel: "A necessidade de desarticular o sistema 'oposicionista' de modo a dividi-lo para ampliar a margem de manobra do governo, o que seria possível com o pluripartidarismo. MACIEL, 2004, p.231.

${ }^{2}$ Igreja e política (Editorial). Mensageiro da Paz, ano L, n.1119. jul. 1980, p.2.

${ }^{3}$ Democracia e Comunismo (Editorial). Mensageiro da Paz, ano LV, n.1181, set. 1985, p.2.

${ }^{4}$ Democracia e Comunismo (Editorial). Mensageiro da Paz, ano LV, n.1181, set. 1985, p.2.

${ }^{5} 15$ de novembro: dia nacional de jejum e oração. Mensageiro da Paz, ano LI, n.1135, nov. 1981, p.2.

${ }^{6}$ Teologia da Libertação: a ponta-de-lança do Anticristo. Mensageiro da Paz, ano L, n.1121, set. 1980, p.6.

${ }^{7}$ Teologia da Libertação: a ponta-de-lança do Anticristo. Mensageiro da Paz, ano L, n.1121, set. 1980, p.6.

${ }^{8}$ Quem tem medo dos crentes. Mensageiro da Paz, ano LVI, n.1162, fev. 1984, p.8.

${ }^{9}$ Os evangélicos e a sucessão presidencial (Editorial). Mensageiro da Paz, ano LV, n.1172, dez. 1984, p.3.

${ }^{10}$ Os evangélicos e a sucessão presidencial (Editorial). Mensageiro da Paz, ano LV, n.1172, dez. 1984, p.3.

${ }^{11}$ Os evangélicos e a sucessão presidencial (Editorial). Mensageiro da Paz, ano LV, n.1172, dez. 1984, p.3.

${ }^{12}$ Tancredo Neves e as Assembleias de Deus (Editorial). Mensageiro da Paz, ano LV, n.1174, fev. 1985, p.2.

${ }^{13}$ Tancredo Neves e as Assembleias de Deus (Editorial). Mensageiro da Paz, ano LV, n.1174, fev. 1985, p.2.

${ }^{14}$ Tancredo Neves e as Assembleias de Deus (Editorial). Mensageiro da Paz, ano LV, n.1174, fev. 1985, p.2.

${ }^{15}$ A morte de Tancredo Neves. Mensageiro da Paz, ano LV, n.1178, jun. 1985, p.10.

${ }^{16}$ A Igreja, a política e a teologia. Mensageiro da Paz, ano LII, n.1142, jun. 1982, p.18.

${ }^{17}$ Pode o crente ser político. Mensageiro da Paz, ano LIV, n.1181, set. 1985, p.6.

${ }^{18}$ A moralidade na Nova República. Mensageiro da Paz, ano LV, n.1176, abr. 1985, p.2.

${ }^{19}$ Por que eleger nossos constituintes. Mensageiro da Paz, ano LIV, n.1179, jul. 1985, p.12.

${ }^{20}$ Por que eleger nossos constituintes. Mensageiro da Paz, ano LIV, n.1179, jul. 1985, p.12. 
${ }^{21}$ Os nossos representantes na constituinte. Mensageiro da Paz, ano LV, n.1177, maio 1985, p.2.

${ }^{22}$ Os nossos candidatos à constituinte (Editorial). Mensageiro da Paz, ano LVI, n.1191, jul. 1986, p.2.

${ }^{23}$ Os nossos candidatos à constituinte (Editorial). Mensageiro da Paz, ano LVI, n.1191, jul. 1986, p.2.

${ }^{24}$ Os rumos da constituinte. Mensageiro da Paz, ano LVI, n.1193, set. 1986, p.15.

${ }^{25}$ Os rumos da constituinte. Mensageiro da Paz, ano LVI, n.1193, set. 1986, p.15.

${ }^{26}$ Os rumos da constituinte. Mensageiro da Paz, ano LVI, n.1193, set. 1986, p.16.

${ }^{27}$ Os rumos da constituinte. Mensageiro da Paz, ano LVI, n.1193, set. 1986, p.16.

${ }^{28}$ Os rumos da constituinte. Mensageiro da Paz, ano LVI, n.1193, set. 1986, p.16.

${ }^{29}$ Os rumos da constituinte. Mensageiro da Paz, ano LVI, n.1193, set. 1986, p.16.

${ }^{30}$ Os rumos da constituinte. Mensageiro da Paz, ano LVI, n.1193, set. 1986, p.16.

${ }^{31}$ Os rumos da constituinte. Mensageiro da Paz, ano LVI, n.1193, set. 1986, p.16.

${ }^{32}$ Os rumos da constituinte. Mensageiro da Paz, ano LVI, n.1193, set. 1986, p.16.

${ }^{33}$ Os rumos da constituinte. Mensageiro da Paz, ano LVI, n.1193, set. 1986, p.16.

${ }^{34}$ Os rumos da constituinte. Mensageiro da Paz, ano LVI, n.1193, set. 1986, p.16.

${ }^{35}$ Paul Charles Freston afirma que durante o processo de redemocratização do país, em meio a crises e avassaladora desigualdade social, as pessoas menos favorecidas economicamente não se voltavam apenas para novas opções religiosas, mas também buscavam novos atores políticos. FRESTON, 1993, p.219.

${ }^{36}$ Assembleia de Deus elege 13 deputados federais. Mensageiro da Paz, ano LVII, n.1197, jan. 1987, p.11.

${ }^{37}$ Assembleia de Deus elege 13 deputados federais. Mensageiro da Paz, ano LVII, n.1197, jan. 1987, p.11.

${ }^{38}$ Constituintes evangélicos: somos contra o aborto. Mensageiro da Paz, ano LVII, n.1200, abr. 1987, p.13.

${ }^{39}$ Acima de tudo a consciência cristã (Editorial). Mensageiro da Paz, ano LVII, n.1204, ago. 1987, p.2.

${ }^{40}$ Qual a solução para o Brasil? Mensageiro da Paz, ano LVIII, n.1218, jun. 1988, p.14.

${ }^{41}$ A carta magna do cristão. Mensageiro da Paz, ano LVIII, n.1221, set. 1988, p.3.

Artigo recebido em 10 de julho de 2012. Aprovado em 22 de outubro de 2014. 